\title{
I believe in God: Content analysis of the first article of the Christian faith based on a literature review
}

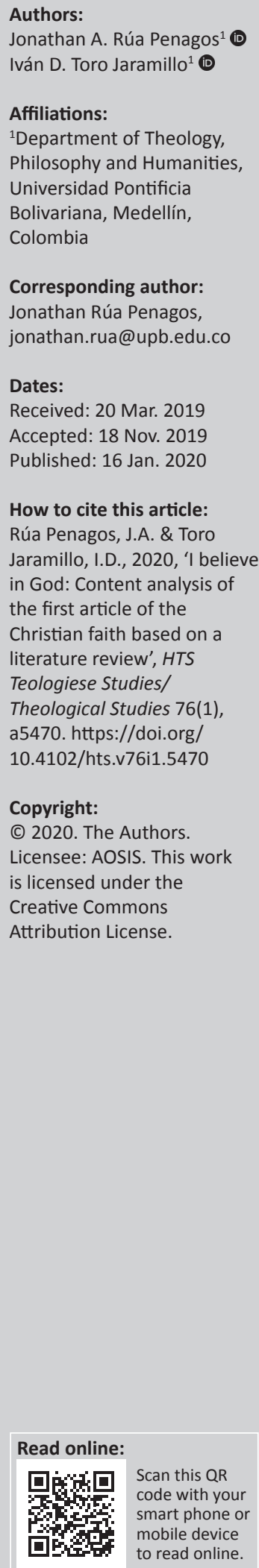

Today, there are different understandings of the first article on the content of the Christian faith, for which an analysis from a theological perspective is necessary. This research sought to reveal the meaning of the first article on the content of the Christian faith in recent theological works that have been produced, through the use of a hermeneutic exercise, conducting a bibliometric and categorical analysis and using NVivo software to analyse the qualitative data. We concluded that the recent theological literature addresses the meaning of the first article of the Christian faith based on the existence, concept and definition of God and his attributes, as well as his power, behaviour, creation, revelation and reign. Although there is little extant material compared to other topics or areas of knowledge that can be explored using these tools, this fact is explained because, normally, theologians are not interested in publishing in high-impact journals. The way of approaching God in contemporary literature can be enriched by taking into account specific contexts, such as poverty, discrimination, suffering, violence, human trafficking, immigration and political realities, in such a way that it is not only a metaphysical reflection of God but also a historical and immanent and even an interreligious research that broadens the concept of the Christian God and answers questions that contemporary society asks in daily life.

Keywords: God; dogmatic theology; Latin American theology; Creed; Christianity.

\section{Introduction}

Today, there are different understandings of the first article on the content of the Christian faith Credo in Deum [I believe in God] - which necessitates an analysis of these interpretations from a theological perspective.

This diversity of views is because of the following multiple factors: the way of following Jesus, sociocultural context, academic training, etc.

Added to this is the fact that there is an apparent diversity between the view of God that is officially practised in the context of Christianity, what the recent theological work develops and the popular concepts in vogue. In other words, there are times in which the continuity in understanding dogma is interrupted, both in content and methodological terms.

This research problem has an aggravating factor, which is that, seemingly, the difference between the understandings of faith grows, and it is very personal when one speaks of a vulnerable, impoverished population or of the periphery. Understanding faith has an educational dimension that often does not reach the borders of the territory, or at the very least, the experience of God lived by the communities is not joined with that considered official and vice versa. Often, popular constructs related to religion are even undervalued.

Because of the above reasons, the following research question was posed: what is the meaning of the first article on the content of the Christian faith in recent theological work? Specifically, the problem seeks to address at least two questions, namely, how is recent academic work characterised in relation to the first article of the Christian faith? and what categories predominate the conceptual framework of that work? Thus, the objective of this research was to reveal the meaning of the first article on the content of the Christian faith in the recent theological works produced, by conducting a bibliometric and categorical analysis, using a hermeneutic exercise, of the most relevant scientific articles of today.

This type of work will justify a form of theological work in the context of the emergence of a new epistemological paradigm that enriches ecclesial action, in the pursuit of effective pastoral 
intervention. This means continuing with a dialogue between content and research methods, not only in theology but also in the philosophical and socio-analytical mediations explored by social and human sciences.

The results of this research will enable the analysis of a range of possibilities in understanding the concept of God on different theoretical levels, which will later serve to make correlations between the understandings that the academicians present and those that the peripheral communities experience. That being the case, theological and pastoral consequences will facilitate a discussion on what we should believe and what we really believe.

\section{Theoretical framework Experience and transcendence}

According to Tillich (1972:61), 'Experience is the means through which sources "speak" to us and we can receive them'. It is the place where human beings meet God (Schillebeeckx 1965). Experience is the way in which human beings connect with life, with everything that exists, and based on this, they build roads and possibilities. This experience is the foundation of knowledge in that it is the initial moment of a logical analysis of what is lived (Müller 1998).

Now, human beings have experienced the possibility of transcending and of preparing to accept the revelation of God (Pié i Ninot 1996), which shows a close relationship between nature and grace (Aguilar de Souza 2004). Rahner (1979)affirmed that human beings are open to being in general, as a possibility, to go towards the Sacred Mystery that drives them towards a radical love and to live in justice. This transcendence is free and historical; it is given here and now, and it favours the conditions for it to operate in what we call salvation in theological terms.

\section{Dogmatic theology}

The field of theology is broad, and its ways of approaching problems are diverse. Hence, there are different areas and disciplines in this science. Dogmatic theology is one of the means of approaching theology. A theologian who has worked the most on this subject is Gerhard Müller, a prefect of the Congregation for the Doctrine of Faith. According to him, faith is the aim of theology, lived in the Church and self-revealed by God through Jesus, where 'the end of this divine self-communication is that men, through Christ, incarnate Word, have access to the Father in the Holy Spirit' (Müller 1998:4-5).

\section{Specifically, dogmatism is (Müller 1998):}

[T]he methodically developed display of reality and the interconnectedness of self-communication, liberator of men, Trinity of God in Jesus Christ, as expressed in the midst of the confession of faith of the Church. (p. 36)

The regressive method, typical of the dogmatic theological approach, allows us to explore the understandings of the contents of faith. Works such as those of Da Costa and Silveira (2015), Freire da Silva (2015), García Rubio (2011), Souza (2012) and Vitor de Oliveira (2010) give an account of this.

\section{Latin American theology}

The discourse on God developed in Latin America has been of high importance in recent decades in the context of world theological work. Besides its academic rigour being recognised, its reflection has been taken into account and also incorporated into papal magisterium - in the Social Doctrine of the Church and in the magisterium of Pope Francis.

Latin American theology, if it can be discussed in the singular, prefers to view the path of God through human beings immersed in contexts typical of reality, rather than speculating about the transcendent reality of God. In other words, research problems that allow for responding to the cries of the people, particularly the poorest, are favoured (Gutiérrez 2000). It also deepens in a form of building theological knowledge that enables other mediations besides philosophical, such as socioanalytical, which include the use of techniques and research instruments of social and human sciences.

\section{The content of the Christian faith}

Classically, we know two versions of the content of faith: the Apostles' Creed and the Nicene-Constantinopolitan Creed. For the delimitation of the problem, we believe it is appropriate to approach the Apostles' Creed in its first article of faith, namely, 'I believe in God, the Almighty Father, Creator of heaven and earth' (Sarot 2016).

Choosing the first article of faith is motivated by the difficulty evident in understanding God and his connection with the experience of life, which would lead to the loss of the meaning of existence, incongruous morality and the dismantling of contemporary social problems. In Christianity, the definitive element for individuals to be happy is their relationship with God (Bento XVI 2010), projected in the community (Fancisco 2013). We approach the first article on the content of the Christian faith, in such a manner as to determine how this dynamic operates in the Church, particularly in the Latin American community.

\section{Methodology}

This research is framed in the context of the historical hermeneutical paradigm (Cifuentes Gil 2011) because it is not an experimental study. This work takes a qualitative approach (Ramos 2015), in that it will focus on values, feelings, imagery and interpretive perspectives of real events. The method guiding this research is hermeneutics, using the philosophical presuppositions of Heidegger (2009) and Gadamer (2004)as a backdrop, in an attempt to understand texts linked to the research problem developed.

To develop the research objectives, we use techniques such as documentary analysis, which, through interpretation, 
will allow for an introduction to scientific books and journals and content analysis (Cáceres 2003), making it possible to reflect on the most representative themes or theoretical perspectives in the text corpus.

Initially, we conducted a search of scientific articles between 2015 and 2018, in English, Portuguese and Spanish, in the Scopus, Web of Science, SciELO, EBSCO, Redalyc and Dialnet databases, using categories such as God, faith, religion, sacred, theology, dogmatic theology, theological anthropology and Latin American theology. A total of 70 texts were found, of which those that were in quartiles were selected, according to the Scimago Journal \& Country Rank (SJR), from which a sample of 35 articles was obtained, based on which the bibliometric and content analysis was carried out.

Some statistical data are presented in relation to the year, place, database, quartile, language and h-index of the selected sample. Subsequently, the content analysis is presented, where a selection of the object of analysis is made, a preanalysis is developed, the units of analysis are defined, rules and classification codes are established, a system of categories (codification) is created and, finally, the final integration of findings is completed. To carry out these procedures, associated with organising, analysing and systematising the results, the qualitative data analysis software NVivo (version 10), created by QSR International, was used.

\section{Ethical consideration}

This article followed all ethical standards for a research without direct contact with human or animal subjects.

\section{Results and discussion}

Next, the results and discussion of the bibliometric and categorical analysis associated with the sample mentioned above are presented.

\section{Bibliometric analysis}

Figure 1 shows that the year with the highest academic output in relation to the categories associated with the first

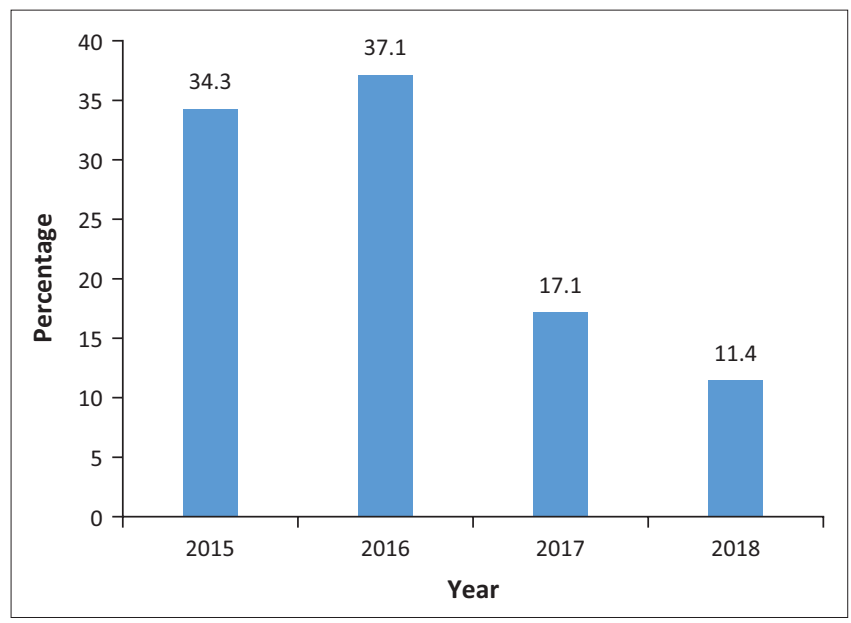

FIGURE 1: Year article was published. article of the Christian faith is 2016. It is notable that 2018 was the year with the lowest production. The above fact can be explained based on the date on which articles were searched for in the databases, which was during 2018, and, by the inclusion criteria, some texts were left out of the sample. In addition, it can be observed that until the peak production year, there was an upward trend that eventually fell.

Whilst it is true that Europe has been a very important continent in the context of producing world theological works, we can see how, little by little, Latin American territories are being incorporated into international academic systems, linking their journals to indexing processes, as in the case of Chile, Colombia and Brazil (Figure 2) .

As can be seen in Figure 3, Scopus continues to be the database with the largest number of articles on the research problem addressed. It indexes a large number of journals from social and human sciences that are then reviewed by the academic community. Web of Science and EBSCO follow in significance. For Web of Science, the low percentage of production in this subject is understandable because the articles published are primarily methodologically developed in a different way from what is usually used in religion

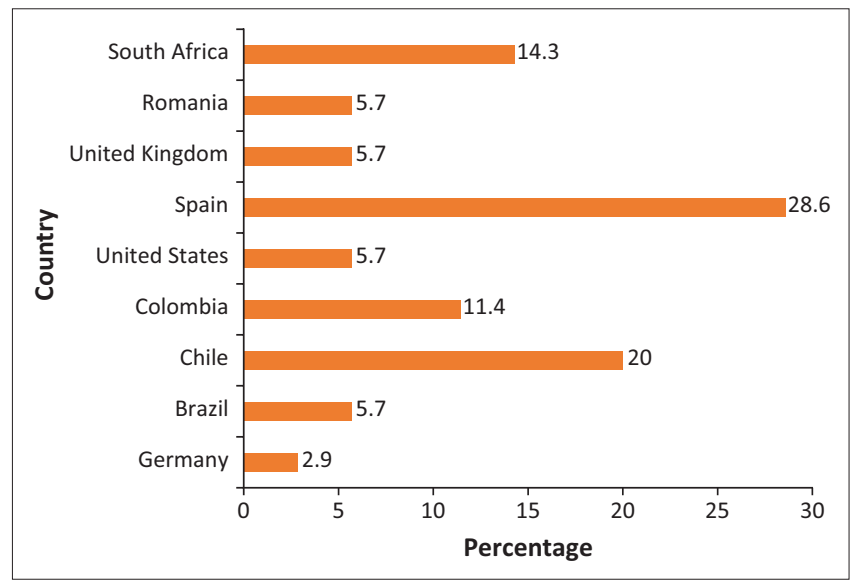

FIGURE 2: Article place of publication.

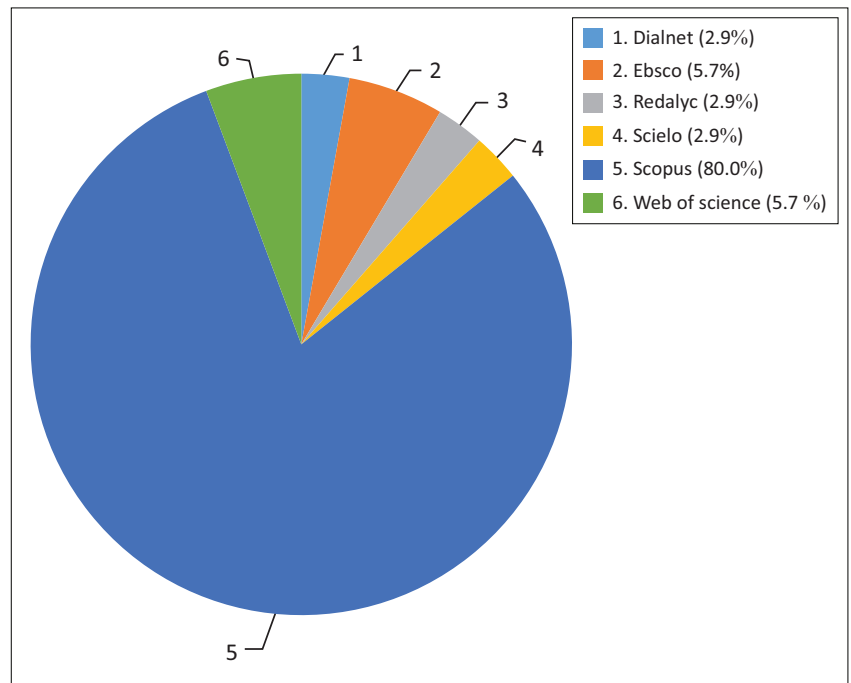

FIGURE 3: Number of articles in databases. 
sciences, which makes it difficult to find many works on these subjects in the Web of Science. EBSCO, in contrast, indexes many journals that do not necessarily have quartiles, so the number of articles recorded in it are reduced.

Considering the $\mathrm{H}$ index, published by SJR, it is evident that the journal with the greatest impact is in the field of natural science (PLoS ONE, 2018), whilst the others on the list are social and human sciences. From the data in Table 1 , it can be concluded that the research problem has been approached from multiple perspectives, not just theological, which shows an interdisciplinary interest in the concept and reality of God.

From Figure 4, it is clear that the vast majority of articles were published in quartiles $1(34 \%)$ and $2(34 \%)$. This shows that they are often-cited publications in the academic production of their respective areas of knowledge. In other words, they are texts with a great impact in the scientific communities.

The ample production in Spanish stands out, which shows an appreciation of the language for the socialisation of the research results, as shown in Figure 5. When comparing this level of production with the impact of the journal in which it is published (Table 1), the most cited journals are noted to be in English. English has been the preferred language for researchers to publish their academic products and ensure, in some way, that they have a high impact. Here, we question, for example, the manner in which Spanish-speaking writers can disseminate their products and at the same time achieve a high impact of publication.

TABLE 1: $\mathrm{H}$ index of the journals with the greatest impact.

\begin{tabular}{|c|c|c|c|}
\hline Journal & Author(s) of the article & Year & $S J R H$ index \\
\hline PLOS ONE & Conrad Jackson, J., Hester, N. \& Gray, K. & 2018 & 241 \\
\hline $\begin{array}{l}\text { Public Understanding } \\
\text { of Science }\end{array}$ & Falade, B.A. \& Bauer, M.W. & 2017 & 61 \\
\hline $\begin{array}{l}\text { Universitas } \\
\text { Psychologica }\end{array}$ & Alves de Souza Filho, E. & 2016 & 17 \\
\hline $\begin{array}{l}\text { Revista de geografía } \\
\text { Norte Grande }\end{array}$ & Paulsen Bilbao, A. & 2015 & 11 \\
\hline Theological Studies & Biernot, D. \& Lombaard, C. & 2017 & 10 \\
\hline
\end{tabular}

SJR, Scimago Journal \& Country Rank.

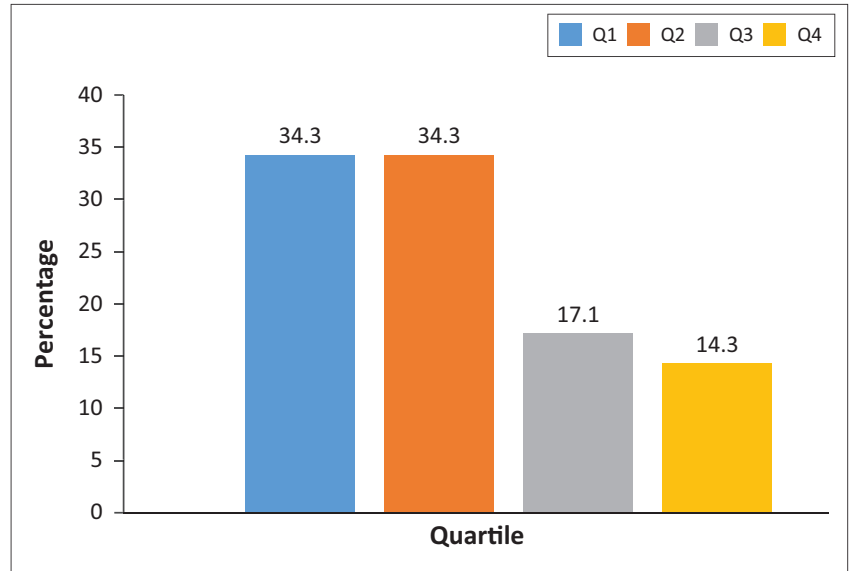

FIGURE 4: Article quartile.
Table 2 shows the frequency of words used by the writers of the articles. Using NVivo software, the 10 most used words in Spanish, English and Portuguese were found. In general, we found that the word 'God' is the most frequent in these texts. The words 'religion' and 'theology' both appear in the column of words in English and in Spanish. The word 'science' is in both columns of words in English and in Portuguese.

The list of words in Spanish reflects theological, anthropological and historical thematic content. Somehow, writers in this language express those interests. For its part, the list of words in English shows a predilection for themes associated with the concept of God, his attributes and the science-faith relationship; Jesus, the individual, appears as a reference, which does not occur in the other columns. The last column, with words in Portuguese, shows a conceptual interest linked to phenomenology, history and the science-religion relationship.

\section{Category analysis}

The present analysis was created on a categorical system that served as a basis for the search and selection of the study corpus. Next, the texts were read, and open coding was completed, where we selected the analysis units using NVivo, in this case fragments with meaning, called nodes. Then, it was appropriate to complete axial coding, grouping the nodes into categories. Finally, the process was finished with selective coding to determine the large category around which the previously developed categorical range revolved (Strauss \& Corbin, 2002).

\section{God}

The analysis carried out through codification (Figure 6) shows that the central node articulating the reflection of academic production in relation to the first article of the Christian faith is the category God. This category is the object of study that interests us regarding the content of the Christian faith as a dogmatic or systematic demonstration of the reality that this concept signifies. Two nodes are associated with the aforementioned category, and they measure its scope, namely, the concept of God and the attributes of God.

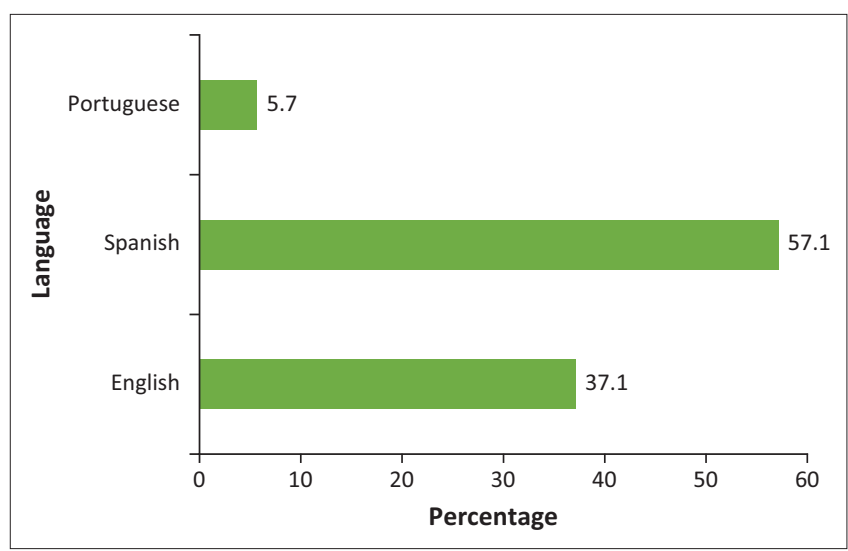

FIGURE 5: Article language. 


\begin{tabular}{|c|c|c|}
\hline Word & Count & Weight (\%) \\
\hline \multicolumn{3}{|l|}{ Spanish } \\
\hline Dios & 1035 & 0.64 \\
\hline Realidad & 438 & 0.27 \\
\hline Religión & 417 & 0.26 \\
\hline Vida & 371 & 0.23 \\
\hline Hombre & 342 & 0.21 \\
\hline Mundo & 310 & 0.19 \\
\hline Teología & 285 & 0.18 \\
\hline Historia & 281 & 0.17 \\
\hline Iglesia & 240 & 0.15 \\
\hline Bien & 237 & 0.15 \\
\hline \multicolumn{3}{|l|}{ English } \\
\hline God & 1838 & 2.64 \\
\hline Religion & 500 & 0.72 \\
\hline Power & 345 & 0.5 \\
\hline Religious & 327 & 0.47 \\
\hline Theology & 320 & 0.46 \\
\hline Experience & 306 & 0.44 \\
\hline Jesus & 300 & 0.43 \\
\hline People & 292 & 0.42 \\
\hline Self & 271 & 0.39 \\
\hline Science & 262 & 0.38 \\
\hline \multicolumn{3}{|l|}{ Portuguese } \\
\hline Duhem & 143 & 0.97 \\
\hline Barroco & 66 & 0.45 \\
\hline História & 65 & 0.44 \\
\hline Sagrado & 64 & 0.43 \\
\hline Pós & 62 & 0.42 \\
\hline Ciência & 50 & 0.34 \\
\hline Modernidade & 50 & 0.34 \\
\hline Teorias & 39 & 0.26 \\
\hline Consumo & 37 & 0.25 \\
\hline Física & 37 & 0.25 \\
\hline
\end{tabular}

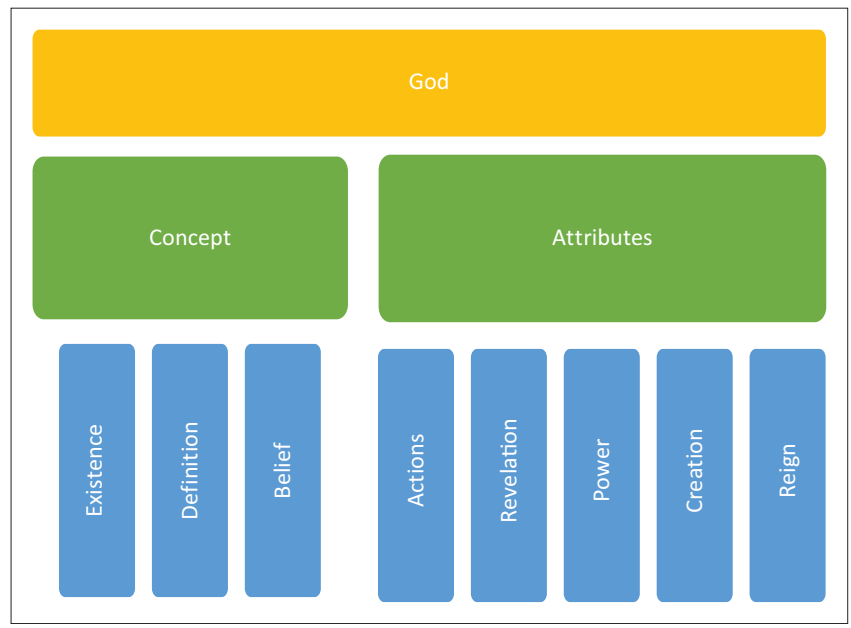

FIGURE 6: Category system resulting from coding.

The concept of God: The existence of God remains a contemporary theme (Alvarado Marambio 2016). Texts continue to show lines of thought that are in favour of or against this premise. There are perspectives based on the notion of providence (Leite 2016) to explain the religious phenomenon. In addition, studies that relate faith and belief (Falade \& Bauer 2018), and others that describe the notion of atheism, from an experience where human beings are valued for themselves (Sala 2016) exist, including scientific argument (Müller 2015).
We could have either a concept or an image of God. When talking about the concept of God, the literature refers to a cognitive process (Counted 2015) that arises from a subject's connection to transcendent reality, 'the real condition of our spiritual being in the world' (Müller 2015:465). The concept of God is different from an image of God, as the latter is associated with emotions and relationships that the person established with caregivers in childhood.

There are multiple ways of defining God: he is the deepest experimental reality (Biernot \& Lombaard 2017); supreme and absolute and the founding reality (Ponzio 2015); personal, eternal and spiritual (Ramos González 2016); the unknowable (Torrijos Castrillejo 2017); or the reality with which humans radically find themselves (Zorroza 2015). These definitions have phenomenological, theological or philosophical connotations (Cortina 2015).

From the relationship between man and God comes believing. This verb can be a way of trusting (Sarot 2016), adhering or surrendering to God (Ponzio 2015), or something that is thought about God (Alves de Souza Filho 2016). In classical theology, this way of approaching the concept of belief is associated with the distinction of fides $q u a$, the act of believing, fides quae, what is believed, sensus fidei, the capacity that a person has to discern in matters of faith and customs and sensus fidelium, which expresses the unity of the community of believers (Schickendantz 2016).

When exploring literature in search of articles related to the category 'God', there is a group of articles that do not refer to God only in terms of Father, but in terms of the relation between the persons of the Trinity.

In other words, the results of this research show that there is a relation amongst all the articles of faith, and focussing on any one of them, in our case the first one, demands the development, even in a collateral way, of diverse theological elements.

There are multiple beliefs about God that depend on the cultural context in which the subject is immersed.

Although the scientific work mentions diverse forms of comprehending God, like the African form (Darlington 2016), undoubtedly, those reflected in the Bible and the Trinitarian dogma prevail. The God of the first Testament has qualities - he speaks, he gets angry, he acts, he rewards, he punishes - whilst the second is a God of love that manifests himself in his Son, Jesus Christ (Edurado 2015).

Trinitarian dogma expresses the oneness of God in three persons: the Father, the Son and the Holy Spirit (Biris 2018; Filtvedt 2017), which are in permanent communion. Although some authors show the relationship between this profession of faith and nonChristian beliefs (Múnera 2016), Christianity has widely developed this tradition. Thus, the Father is not so much a cultural designation that offers security to a group of people, as one would say from a psychoanalytic reading (Ramos González 
2016), but he is a Trinity person who makes it possible to live an experience of closeness, fidelity and creation (Sarot 2016).

The Son is the manner in which God reveals himself fully and through which humans discover their identity (Sala 2016), the subject and object of faith, by whom human beings are mobilised towards God, grace, the bearer of good news, gospel, the message of conversion and liberation (Niño de Zepeda Gumucio 2015). He is subsequently announced in the Kerygma by the community (Edurado 2015), which participates as a Church in constructing the Kingdom of God (Pellegrino 2017), always called to dialogue, the justice, the common good, the centrality of human beings in social life (Cabrera 2016) and a commitment to the poorest.

The Spirit of God guides individuals towards an eschatological reality, where hope remains and the process of salvation brought by Jesus becomes historical (Ducay \& GonzálezAlonso 2016), which may or may not be accepted by human free will, and which shows, in some way, what in the theological tradition is noted as heaven, namely, a joyful eternal life, far removed from any possibility of breaking from God (Stratton \& Erasmus 2018).

The attributes of God: When recent literature approaches the notion of God, it also describes or characterises him: the attributes of God emerge, qualities that in some way express his reality and the way in which human beings perceive him. God acts and manifests his will in history (Niño de Zepeda Gumucio 2015). He is dynamic and reveals who he is, he does it in his creation (Pellegrino 2017) and in history. Although, a 'private revelation' has been spoken of, given to someone after the death of the last apostle, in addition to a 'public revelation', not binding for Christianity (Schickendantz 2016), the revelation in Jesus is the definitive standard for the Christian community. Through him, we can fully know who God is (Filtvedt 2017).

God is powerful. Power can be viewed as oppression and domination of the other or as recognition of the authorship of God in the life processes. In other words, to say that God is powerful would consist of affirming that he is the sustenance and cause of everything that exists (Muis 2016). When it is affirmed that God creates, it is also said that he grants the necessary conditions for human beings to conserve and recreate what he did, there is a margin of freedom rather than determinism in this process (Stratton \& Erasmus, 2018). This statement 'creating heaven and earth', rather than being understood literally, shows a close and dependent relationship between God and everything he created (Sarot 2016). All things, and especially human beings, have a trace of God; hence, it is said that they are the image and likeness of their creator (Zorroza 2015). God, the powerful one, who sustains everything that exists, reigns. The reign of God shows a reality that happens permanently and will come to an end with the consummation of all things (Sala 2016). To say that God reigns, as demonstrated by Jesus of Nazareth, means that he takes charge of his creation and seeks the necessary conditions for its well-being.

\section{Conclusion}

When looking at databases regarding recent academic work in relation to the first article of the Christian faith, we concluded that there is little material compared to other topics or areas of knowledge that can be explored using these tools. This is explained because, normally, theologians are not concerned with publishing in high-impact journals. However, the globalisation of knowledge is motivating the community to slowly incorporate into these systems. This introduces the challenge of sharing knowledge through these forms that emerge in the world without leaving aside the classic ways associated with publishing books and journals without the goal of indexation.

The categories that prevail in the conceptual framework of the academic works we found have to do with the concept and attributes of God. The texts address problems associated with the existence, definition and belief in transcendent reality as well as with the actions, revelation, power, creation and the reign of God.

Considering the above, this way of approaching God can be enriched by taking into account specific contexts, such as poverty, discrimination, suffering, violence, human trafficking, immigration and political realities, in such a way that is not only a metaphysical reflection of God but also historical and immanent.

The meaning of the first article on the content of the Christian faith in recent theological work shows a tendency to imagine the existence of God, a God who is perceived, preferably, from the Judeo-Christian tradition as creator, foundation of everything that exists, one in three people, powerful and reigning and who creates conditions for human beings to live as saved. This line of work can be strengthened with interreligious research that broadens the concept of the Christian God and responds to questions that the contemporary society asks in daily life.

\section{Acknowledgements}

We thank the participants of this research and who somehow contributed to it being developed.

\section{Competing interests}

The authors have declared that no competing interests exist.

\section{Author's contributions}

All authors contributed equally to this work.

\section{Funding information}

This research received specific grant from Universidad Pontificia Bolivariana (UPB).

\section{Data availability statement}

Data sharing is not applicable to this article as no new data were created or analysed in this study. 


\section{Disclaimer}

The views and opinions expressed in this article are those of the authors and do not necessarily reflect the official policy or position of any affiliated agency of the authors.

\section{References}

Aguilar de Souza, J.C., 2004, 'Matrizes antropológicas para a compreensão do problema da natureza e da graça em Karl Rahner', Horizonte 3(5), 131-141.

Alvarado Marambio, J.T., 2016, '¿Qué es una "religión”? Tres teorías recientes', 'llu. Revista de Ciencias de las Religiones 21,31-49. https://doi.org/10.5209/ ILUR.53839

Alves de Souza Filho, E., 2016, 'God representation, self representation, and educational experience among university students in Rio de Janeiro', Universitas Psychologica 15(1), 361-382. https://doi.org/10.11144/Javeriana.upsy15-1.grsr

Anon., 1998, Biblia de Jerusalén, Desclée De Brouwer, Bilbao.

Bento XVI, 2010, Verbum Domini. Exortação apostólica pós-sinodal sobre a palavra de deus na vida e na missão da Igreja, Libreria Editrice Vaticana, Roma.

Biernot, D. \& Lombaard, C., 2017, 'Religious experience in the current theological discussion and in the church pew', HTS Theological Studies 73(3), 1-12. https:// doi.org/10.4102/hts.v73i3.4347

Biris, I., 2018, 'On the logic the Christian trinity: Co-inherence and the nesting relationships', Journal for the Study of Religions \& Ideologies 17(50), 17-29.

Cabrera, A.O., 2016, 'Pensamiento social desde la antropología y ética en perspectiva teológica: Claves para la pedagogía en el humanismo-valores de la doctrina social de la iglesia', Cauriensia 11, 757-768.

Cáceres, P., 2003, 'Análisis cualitativo de contenido: Una alternativa metodológica alcanzable', Psicoperspectivas 2(1), 53-82.

Cifuentes Gil, R.M., 2011, Diseño de proyectos de investigación cualitativa, Noveduc, Buenos Aires.

Cortina, A., 2015, 'José Luis Aranguren. Religión pensada, religión vivida', Isegoría (52), 167-185. https://doi.org/10.3989/isegoria.2015.052.07

Counted, V., 2015, 'Understanding God images and God concepts: Towards a pastora hermeneutics of the God attachment experience', Verbum et Ecclesia 36(1), 1-14. https://doi.org/10.4102/ve.v36i1.1389

Da Costa, R. \& Silveira, S., 2015, 'Como Deus é ciente em sua essência divina', Trans/Form/Ação 38(2), 9-34. https://doi.org/10.1590/S0101-31732015000 200002

Darlington, V., 2016, 'From theology to theologies', Black Theology 14(2), 152-168. https://doi.org/10.1080/14769948.2016.1185849

Ducay, A. \& González-Alonso, P., 2016, 'La fórmula "pro multis": Perspectiva bíblica y dogmática', Scripta Theologica 48(3), 753-771. https://doi.org/10.15581/ 006.48.3.753-771

Eduardo, V.A., 2015, 'Kerigma: Preguntas teóricas en torno a la primera evangelización de América (Antillas, 1510-Nueva España, 1524)', Historia Crítica 58(58), 13-32. https://doi.org/10.7440/histcrit58.2015.01

Falade, B.A. \& Bauer, M.W., 2018, “I have faith in science and in God”: Common sense, cognitive polyphasia and attitudes to science in Nigeria', Public Understanding of Science 27(1), 29-46. https://doi.org/10.1177/0963662517690293

Fancisco, 2013, Lumen Fidei. Carta encíclica sobre a fé, Libreria Editrice Vaticana, Roma.

Filtvedt, O.J., 2017, 'The transcendence and visibility of the Father in the Gospel of John', Zeitschrift für die neutestamentliche Wissenschaft 108(1), 90-118. https:// doi.org/10.1515/znw-2017-0003

Freire da Silva, M., 2015, 'Trindade e apofatismo no pensamento de Gregório de Nissa', ATeo 19(50), 330-351. https://doi.org/10.17771/PUCRio.ATeo.25504
Gadamer, H.-G., 2004, Verdad y método, 6th edn., Sígueme, Salamanca.

García Rubio, A., 2011, 'A Visão Científica Evolucionista Interpela a Fé em Deus Criador', Atualidade Teológica 15(37), 47-65. https://doi.org/10.17771/PUCRio.ATeo.18911 Gutiérrez, G., 2000, Teologia da libertação. Perspectivas, Edições Loyola, São Paulo. Heidegger, M., 2009, Ser y tiempo, 2nd edn., Trotta, Madrid.

Leite, F.R., 2016, 'Um Argumento a Favor da Existência de Deus Formulado por Pierre Duhem', Trans/Form/Ação 39(4), 33-58. https://doi.org/10.1590/S010131732016000400003

Muis, J., 2016, 'Rethinking the creative power of God', HTS Theological Studies 72(4), 1-7. https://doi.org/10.4102/hts.v72i4.3842

Müller, G., 1998, Dogmática, Herder, España.

Müller, G.L.C., 2015, 'Al Dios cristiano desde el ateísmo moderno', Teología y vida 56(4), 461-469. https://doi.org/10.4067/S0049-34492015000400005

Múnera, J.C., 2016, 'De Apologética Trinitaria al Diálogo Interreligioso', Teología y vida 57(1), 95-115. https://doi.org/10.4067/S0049-34492016000100004

Niño de Zepeda Gumucio, R., 2015, 'Fe y cultura en las reflexiones teológicas de Comblin, Scannone y Trigo: Convergencias y diferencias', Veritas 33, 183-201. https://doi.org/10.4067/S0718-92732015000200010

Paulsen Bilbao, A., 2015, 'Discursos e imaginarios de cielo de líderes evangélicos de Santiago de Chile (2012-2014): ¿concepciones teocéntricas o antropocéntricas?', Revista de geografía Norte Grande 61, 65-89.

Pellegrino, L., 2017, 'Las historias de vida en el método de planificación pastoral ver-juzgar-actuar', Veritas 36, 113-133. https://doi.org/10.4067/S0718-92732 017000100006

Pié i Ninot, S., 1996, Tratado de teología fundamental, 3rd edn., Secretariado Trinitario, Salamanca.

Ponzio, P., 2015, 'La experiencia como paradigma del nexo entre el hombre y Dios', Pensamiento Revista de Investigación e Información Filosófica 71(266), 413-424. https://doi.org/10.14422/pen.v71.i266.y2015.009

Rahner, K., 1979, Curso fundamental sobre la fe, Herder, Barcelona.

Ramos, C.A., 2015, 'Los paradigmas de la investigación científica', Av.psicol 23(1), 9-17. https://doi.org/10.33539/avpsicol.2015.v23n1.167

Ramos González, A., 2016, 'Ateísmo y espiritualidad', 'llu. Revista de Ciencias de las Religiones 21, 165-183. https://doi.org/10.5209/ILUR.53851

Sala, R., 2016, 'Monseñor Romero y la escatología de Gaudium et Spes', Teología y vida 57(2), 185-209. https://doi.org/10.4067/S0049-34492016000200002

Sarot, M., 2016, 'Believing in God the Father: Interpreting a phrase from the Apostle's Creed', Theological Studies 72(4), 1-4. https://doi.org/10.4102/hts.v72i4.3287

Schickendantz, C., 2016, 'Un cambio en la ratio fidei: Asociación (aparentemente ilícita) entre principios teológicos y datos empíricos', Teología y vida $57(2)$ 157-184. https://doi.org/10.4067/S0049-34492016000200001

Schillebeeckx, E., 1965, Cristo, sacramento del encuentro con Dios, Dinor, San Sebastián.

Souza, I., 2012, 'Reflexão cristológico-trinitária', Atualidade Teológica 16(40), 72-86.

Stratton, T. \& Erasmus, J., 2018, 'Divine determinism and the problem of hell', Perichoresis 16(2), 3-15. https://doi.org/10.2478/perc-2018-0007

Strauss, A. \& Corbin, J., 2002, Bases de la investigación cualitativa. Técnicas y procedimientos para desarrollar la teoría fundamentada, Editorial Universidad de Antioquia, Medellín.

Tillich, P., 1972, Teología sistemática, Ariel, Barcelona.

Torrijos Castrillejo, D., 2017, '¿Dios con o sin el ser? Apuntes acerca de la onto-teología', Espíritu 66(153), 71-86. https://doi.org/10.36576/summa.48619

Vitor de Oliveira, I., 2010, 'Deus: metafísica e pensar pós-metafísico', Horizonte 8(16), 8-11. https://doi.org/10.5752/P.2175-5841.2010v8n16p8

Zorroza, M.I., 2015, 'Trascendencia y apertura: Una imagen de hombre para nuestro tiempo', Cauriensia 10, 459-471. 